\title{
Issues Related to EM Management of DOE Spent Nuclear Fuel
}

\author{
D. G. Abbott \\ M. S. Abashian ${ }^{a}$ \\ S. Chakraborti ${ }^{\mathrm{a}}$ \\ K. Roberson ${ }^{a}$ \\ J. M. Meloin ${ }^{a}$ \\ Published July 1993 \\ Idaho National Engineering Laboratory \\ EG\&G Idaho, Inc. \\ Idaho Falls, Idaho 83415
}

Prepared for the

U.S. Department of Energy

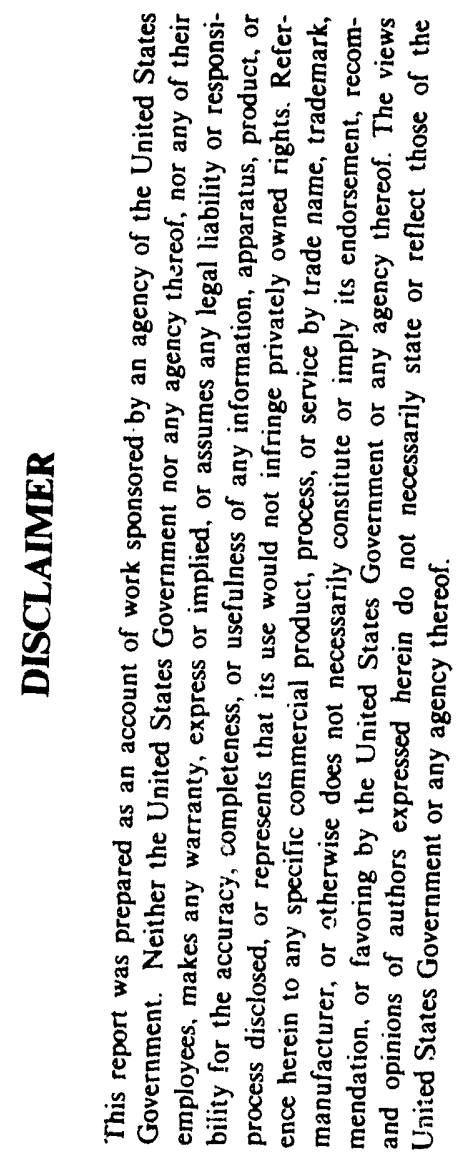

Office of Environmental Restoration and Waste Management

Under DOE Idaho Fleld Office

Contract DE-AC07-76ID01570

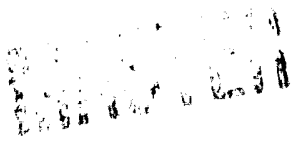

a. IT Corporation. 


\section{CONTENTS}

ACRONYMS $\ldots \ldots \ldots \ldots \ldots \ldots \ldots \ldots \ldots \ldots \ldots \ldots \ldots \ldots \ldots \ldots \ldots \ldots$

INTRODUCTION $\ldots \ldots \ldots \ldots \ldots \ldots \ldots \ldots \ldots \ldots \ldots \ldots \ldots \ldots \ldots \ldots \ldots$

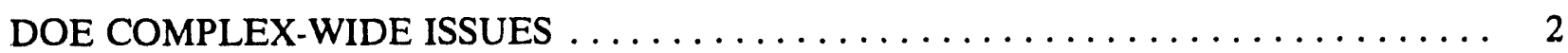

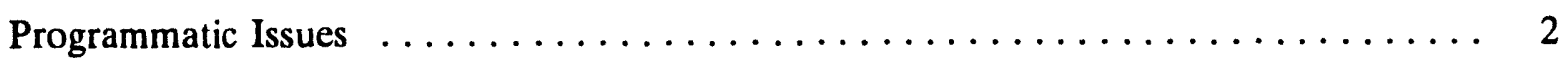

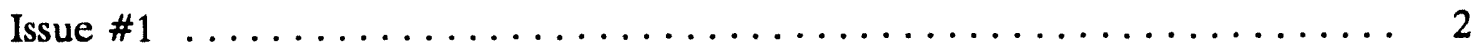

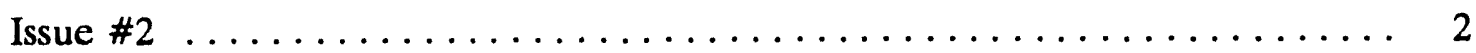

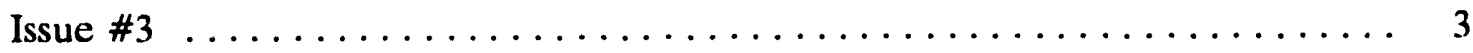

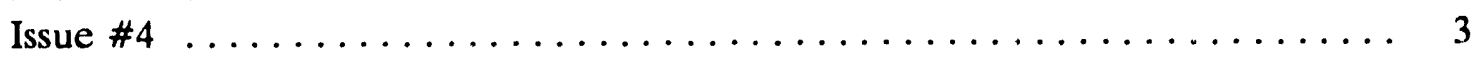

Waste Sources and Generation $\ldots \ldots \ldots \ldots \ldots \ldots \ldots \ldots \ldots \ldots \ldots \ldots$

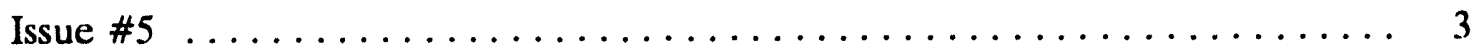

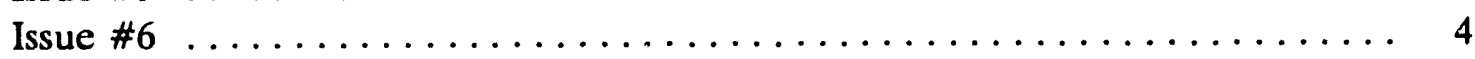

Treatment and Consolidation $\ldots \ldots \ldots \ldots \ldots \ldots \ldots \ldots \ldots \ldots \ldots \ldots \ldots$

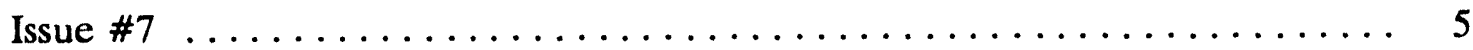

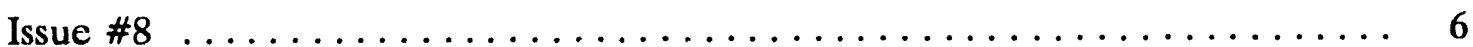

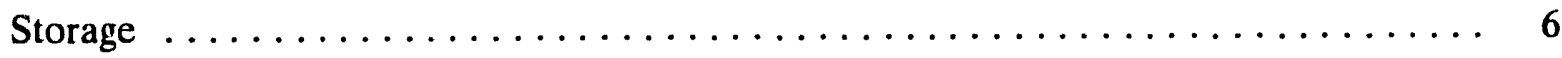

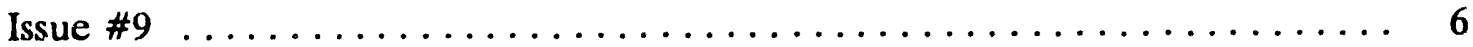

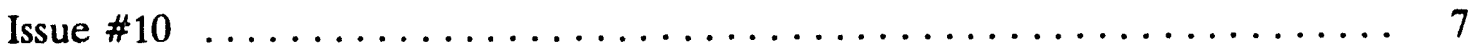

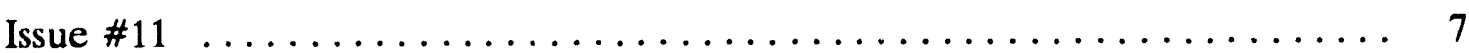

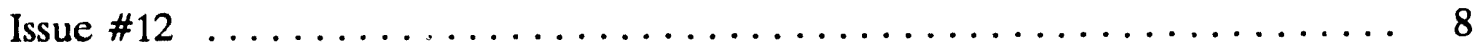

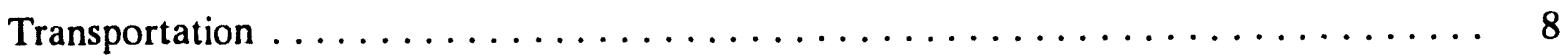

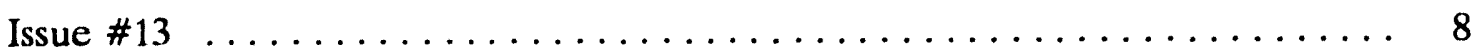

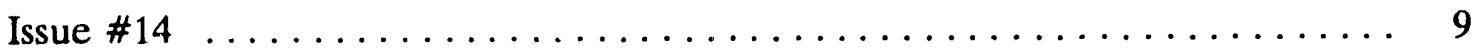

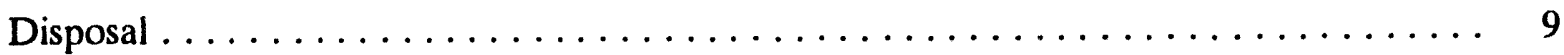

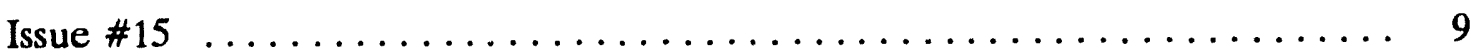

SITE-SPECIFIC ISSUES $\ldots \ldots \ldots \ldots \ldots \ldots \ldots \ldots \ldots \ldots \ldots \ldots \ldots \ldots \ldots$

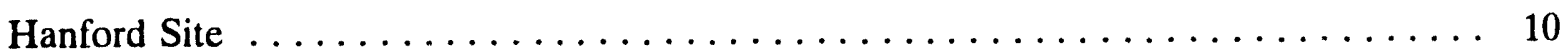

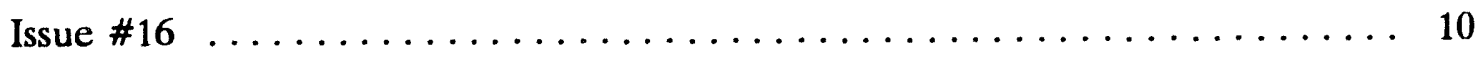

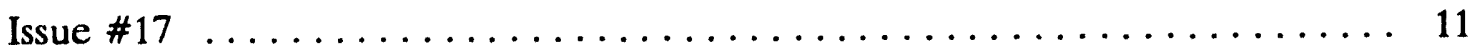




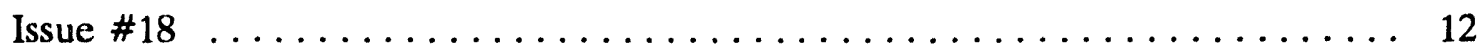

Idaho National Engineering Laboratory $\ldots \ldots \ldots \ldots \ldots \ldots \ldots \ldots \ldots \ldots \ldots \ldots$

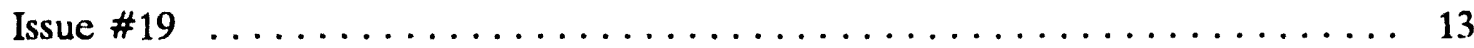

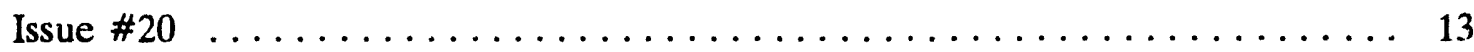

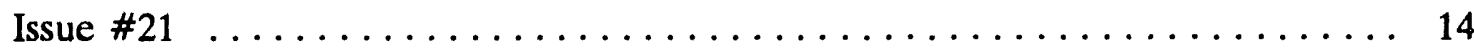

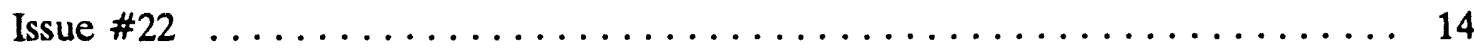

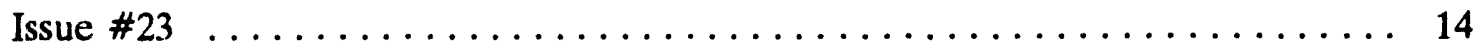

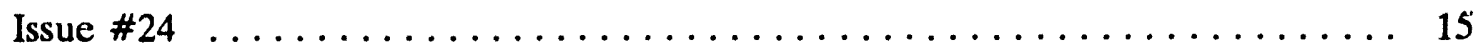

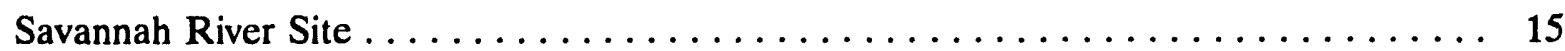

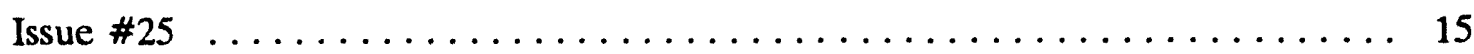

West Valley Demonstration Project $\ldots \ldots \ldots \ldots \ldots \ldots \ldots \ldots \ldots \ldots \ldots \ldots$

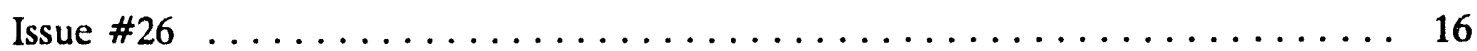

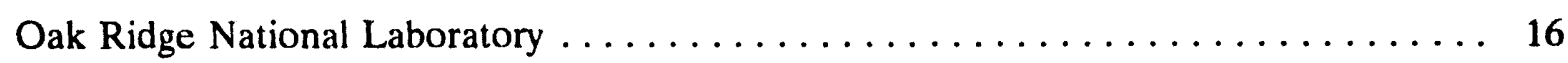

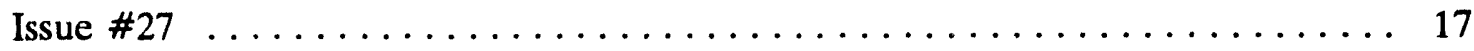

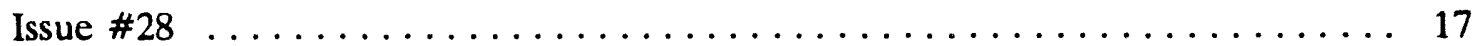

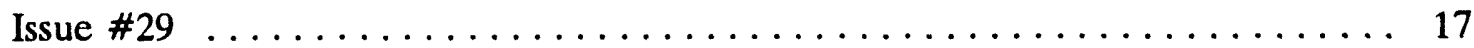

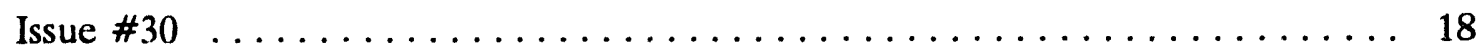

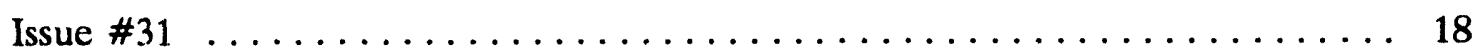

Brookhaven National Laboratory $\ldots \ldots \ldots \ldots \ldots \ldots \ldots \ldots \ldots \ldots \ldots \ldots \ldots$

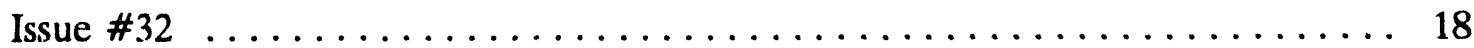

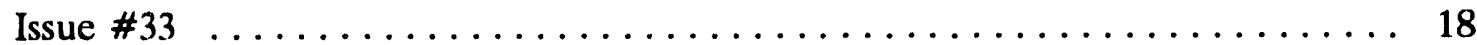

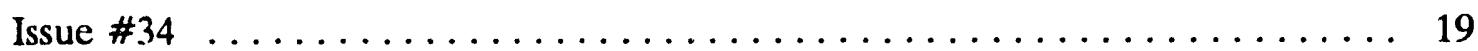

Sandia National Laboratories . . . . . . . . . . . . . . . . . . . . . . 19

Los Alamos National Laboratory $\ldots \ldots \ldots \ldots \ldots \ldots \ldots \ldots \ldots \ldots \ldots$

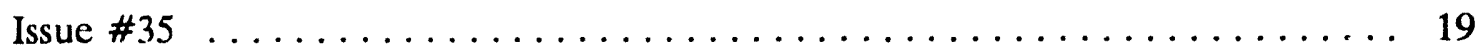

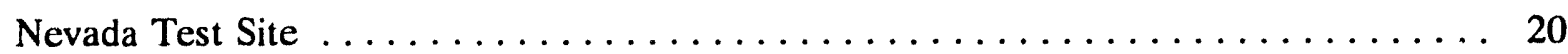

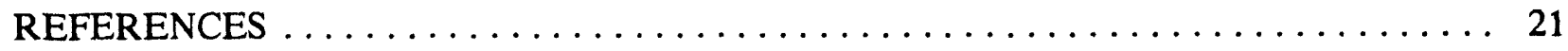

Spent Fuel Issues Report iv 


\section{ACRONYMS}

AEA

ANL-W

ATR

BRD

BSR

CFR

DOE

EIS

EM

EPA

FFTF

FY

HFBR

HFIR

ICPP

INEL

LANL

MRS

NRC

NRF

OCRWM

ORNL

PBF
Atomic Energy Act

Argonne National Laboratory-West (INEL)

Advanced Test Reactor (INEL)

Brookhaven Reactor Division

Bulk Shielding Reactor (ORNL)

Code of Federal Regulations

Department of Energy

environmental impact statement

Environmental Restoration and Waste Management (DOE)

Environmental Protection Agency

Fast Flux Test Facility (Hanford)

fiscal year

High Flux Beam Reactor (Brookhaven)

High Flux Isotope Reactor (ORNL)

Idaho Chemical Processing Plant (INEL)

Idaho National Engineering Laboratory

Los Alamos National Laboratory

monitored retrievable storage

Nuclear Regulatory Commission

Naval Reactor Facility

Office of Civilian Radioactive Waste Management

Oak Ridge National Laboratory

Power Burst Reactor (INEL) 
PNL

PWR

RCRA

SNF

SPR

SRS

TAN

TMI

TRA
Pacific Northwest Laboratory

pressurized water reactor

Resource Conservation and Recovery Act

spent nuclear fuel

Singe Pass Reactor (Hanford)

Savannah River Site

Test Area North (INEL)

Three Mile Island

Test Reactor Area (INEL) 


\section{Issues Related to EM Management of DOE Spent Nuclear Fuel}

\section{INTRODUCTION}

This document is a summary of the important issues involved in managing spent nuclear fuel (SNF) owned by the Department of Energy (DOE). Issues related to civilian SNF activities are not discussed. DOE-owned SNF is stored primarily at the Hanford Site, Idaho National Engineering Laboratory (INEL), Savannah River Site (SRS), Oak Ridge National Laboratory (ORNL), and West Valley Demonstration Project. Smaller quantities of SNF are stored at Brookhaven National Laboratory, Sandia National Laboratories, and Los Alamos National Laboratory (LANL). There is a wide variety of fuel types, including both low and high enrichment fuels from weapons production, DOE reactors, research and development programs, naval programs, and universities. Most fuel is stored in pools associated with reactor or reprocessing facilities. Smaller quantities are in dry storage. Physical conditions of the fuel range from excellent to poor or severely damaged.

An issue is defined as an important question that must be answered or decision that must be made on a topic or subject relevant to achieving the complimentary objectives of (a) storing SNF in compliance with applicable regulations and orders until it can be disposed, and (b) safely disposing of DOE's SNF. The purpose of this document is to define the issues; no recommendations are made on resolutions. As DOE's national SNF management program is implemented, a system of issues identification, documentation, tracking, and resolution will be implemented. This document is an initial effort at issues identification.

The first section of this document is an overview of issues that are common to several or all DOE facilities that manage SNF. The common issues are organized according to specific aspects of spent fuel management. This is followed by discussions of management issues that apply specifically to individual DOE facilities. The last section provides literature references. 


\section{DOE COMPLEX-WIDE ISSUES}

The major management issues at most facilities are not unique to individual sites, but are common throughout the DOE complex. These issues are discussed in the following subsections.

\section{Programmatic Issues}

\section{Issue \#1}

Should DOE's SNF be considered a waste?

Discussion. SNF has not been considered a waste because it could be reprocessed to recover fissile materials for recycling. In 1992, DOE decided that SNF will not be reprocessed in DOE facilities solely for recovery of highly enriched uranium, nor will other DOE programs support recovery of plutonium-239 in these facilities from spent fuel for advanced reactor usage. Instead, SNF will be stored pending geologic disposal or other future actions, such as reprocessing at a future date if circumstances warrant (DOE News Release, 1992).

The decision not to reprocess changed the status of SNF. Instead of being stored for the short term while awaiting reprocessing, it must now be in long-term storage to await disposal. DOE Order 5820.2A, Radioactive Waste Management, establishes DOE policies, guidelines, and minimum requirements by which DOE manages its radioactive and mixed waste and contaminated facilities. The Order defines radioactive waste as "solid, liquid, or gaseous material that contains radionuclides regulated under the Atomic Energy Act of 1954, as amended and of negligible economic value considering costs of recovery." With the curtailment of reprocessing, SNF now falls within the definition of waste in DOE Order 5820.2A.

All future Environmental Restoration and Waste Management (EM) planning will categorize high-level waste, low-level waste, etc., and will recognize that SNF will no longer be considered a resource in the sense of being a source of special nuclear material. Sites that have not factored SNF into overall waste management plans have received EM guidance to that effect.

In addition to intact fuel, it must be determined if some fuel-related materials such as nonfuelbearing components from consolidation, fuel pieces, unirradiated fuel that has no future use, and severely damaged fuel, should be categorized with SNF.

\section{Issue \#2}

How will DOE deal with institutional issues related to public and State and local government involvement in DOE's decisionmaking process regarding topics such as fuel receipts, increasing storage capacity, and shipments?

Discussion. State and other governments in areas that host DOE sites, as well as concerned private entities, have taken an increasingly active interest in DOE's management of SNF (Bechtel, 1986; Pellettieri and Welles, 1985). DOE has increased its emphasis on openness and involving these parties in the political process of decisionmaking. Experience in transporting spent fuel and siting 
the monitored retrievable storage (MRS) facility has shown the value of a well-planned and carefully executed approach to dealing with institution issues (Smith, 1988; McLeod, 1992). Proactive involvement of interested parties before decisions are made should reduce opposition and enhance implementation of the decision. This includes identification of state issues and regulatory constraints in those states where DOE has storage facilities and that thus would likely receive offsite fuel for storage. It is also very important that DOE plan its approach towards dealing with the United States Congress regarding funding and regulations affecting SNF management. An institutional plan should be developed as part of DOE's spent fuel management program.

\section{Issue \#3}

The DOE organizations responsible for owning and funding management of the various fuel types must be determined, and a single departmental approach and position on interrelated activities must be implemented.

Discussion. DOE-managed spent fuel may be "owned" by one of several offices within DOE, or in rare cases, by an outside agency such as the Nuclear Regulatory Commission (NRC) or a private utility. Ownership for each type of fuel must be documented along with other inventory information. As a policy, DOE is planning to transfer ownership of DOE-owned spent fuel to EM. Plans must be developed for orderly transfer and for determination of funding issues related to ownership. Where outside agencies are involved, issues related to ownership and funding must be fully identified and plans for resolution must be established and implemented. Also, SNF activities planned and performed by various organizations within DOE and its operating contractors must be coordinated, such as the EM Programmatic Environmental Impact Statement, SNF Strategic Plan, SNF Management Program Plan, and site-specific National Environmental Policy Act (NEPA) actions. A related concern is that spent fuel owned by one office may be located in a facility managed by another office. For example, fuel at West Valley is owned by the Office of Civilian Radioactive Waste Management (OCRWM), but the facility is managed by EM.

\section{Issue \#4}

Quality assurance requirements for spent fuel activities need to be established to ensure consistent application and compatibility between program elements.

Discussion. Quality assurance requirements have evolved over time. DOE has issued DOE Order 5700.6C, Quality Assurance, which governs DOE quality operations. The OCRWM, which is developing the repository and MRS, has its own quality assurance program requirements (Quality Assurance Manual, DOE/RW-0214). Thus, there is a potential for significant differences in quality programs, which could affect the ability to store or dispose of DOE's fuel. A consistent application of quality assurance requirements is needed where DOE and OCRWM activities interface.

\section{Waste Sources and Generation}

\section{Issue \#5}

SNF inventories and conditions need to be thoroughly and accurately documented, including anticipated new receipts and removals from inventory. 
Discussion. In order to make informed, relevant decisions about the management of SNF, a comprehensive, accurate, and accessible up-to-date database is needed. At present, the inventories of spent fuel in DOE's possession and the condition of this material are not always well-defined, nor is the information readily available.

Information on spent fuel is available in the Integrated Data Base (DOE, 1991a), the Materials Not Classified as Waste study (Tuck, 1990), and probably other sources. Also, each site maintains its own inventory information. The Nuclear Materials Management and Safeguards System (NMMSS) is the Safeguards and Security national database and information support system for nuclear materials controlled by the United States Government, and it includes spent fuel. Information from these sources needs to be collected, evaluated, and verified, and discrepancies need to be resolved. Also, the inventory should document current estimates on rate of receipt of offsite fuels from domestic and foreign reactors in the future.

Stored spent fuel needs to be analyzed for characteristics such as enrichment, radionuclides, geometry, materials of construction, burnup, decay time, heat generation, radiation levels, condition, and RCRA constituents. These characteristics are secessary to assess storage and processing requirements, and suitability for the national repository. Such information would also indicate if the spent fuel has a potential for regulation under the Resource Conservation and Recovery Act (RCRA). DOE has many types of experimental fuels and fuels from a number of research and development programs that have been in storage for many years, some of which are probably poorly characterized. The largest mass (or volume) of DOE SNF, ramely, production, naval propulsion, and test reactor, are probably characterized sufficiently to provide a basis for initial considerations of treatment technologies for treatment, storage, transportation, and disposal needs. These evaluations need to be documented.

The inventory should include the current status of DOE and other domestic research reactors, the date when they run out of available SNF storage space, and the impacts to the nation and society if research reactors shut down.

\section{Issue \#6}

The applicability of RCRA mixed hazardous waste regulations to SNF must be determined for storage and disposal.

Discussion. DOE is authorized to regulate storage and management of its own SNF under the Atomic Energy Act of 1954 (AEA) and the Department of Energy Organization Act. Commercial SNF in long-term storage is regulated by the NRC. Under the Nuclear Waste Policy Act of 1982 , DOE is required to take title to all SNF, which will be disposed in a geologic repository licensed by the NRC.

The Resource Conservation and Recovery Act of 1976 covers management of hazardous waste, excepting materials or activities regulated under the AEA. It has been determined that under RCRA, the Environmental Protection Agency (EPA) has authority to regulate the nonradioactive component of mixed hazardous and radioactive waste. DOE has determined that the AEA exception covers only the actual radionuclides dispersed or suspended in the waste substance, and the nonradioactive 
material would be handled in accordance with RCRA regulations. Thus, if SNF includes constituents that constitute a hazardous waste, it will be regulated under both the AEA and RCRA.

To date, the EPA has not taken a position on RCRA applicability to spent fuel. A study commissioned by the EPA (EPA, 1990) concluded that most spent fuel is unlikely to be mixed waste. The states and EPA have shown no interest in regulating storage of commercial fuel. Certain DOE fuels, such as liquid spent fuel, fuels containing reactive metals, or other unique materials such as Three Mile Island core debris, may exhibit RCRA characteristics, in which case they could be subject to $\mathrm{RCRA}$ regulation.

A determination that spent fuel is mixed waste would have far-reaching implications. The EPA, as well as states with mixed waste regulatory authority, would have authority over the handling of spent fuel and enforce compliance with RCRA regulations. Existing rules and practices authorized by DOE would be complicated by overlaying additional RCRA requirements. Fuel pools and other storage facilities might have to seek permits as RCRA storage facilities. The possible classification of some SNF as a mixed waste hinges on the regulatory definition of hazardous waste and the physical and chemical characteristics of spent fuel. Studies of individual fuel types would be needed to assess their applicability.

Disposal of spent fuel is the responsibility of DOE. Ultimate disposal will be in a geologic repository licensed by the NRC. If some SNF is shown to contain RCRA-regulated constituents, it would constitute a mixed waste and, therefore, be subject to dual regulation by the EPA and NRC. It is uncertain whether DOE would seek (or be granted) a variance from a land disposal prohibition based on, for example, a demonstration of no migration of the hazardous constituents. DOE and the EPA will have to resolve the mixed waste issue as it applies to SNF, and DOE may have to treat, to EPA standards, any DOE SNF that is determined to be mixed waste.

\section{Treatment and Consolidation}

\section{Issue \#7}

Repository waste acceptance criteria (WAC) are needed to determine fuel conditioning requirements.

Discussion. Some forms of spent fuel can be stored in their present condition, with little processing or conditioning required. These would generally include fuels with stable materials and configurations that have been uperated and stored in a manner that has not caused damage. Others will require some form of treatment or conditioning simply to ensure that they will remain in a safe condition during storage. For example, some fuels are damaged as a result of operation in the reactor, or storage under conditions that degraded the fuel condition. Eventually, fuels are also likely to require conditioning before shipment the repository to meet WAC. To reduce costs from processing and to ensure that processing is only done once, WAC are needed to design processes that will satisfy requirements for both onsite storage and the repository. 


\section{Issue \#8}

SNF processing or conditioning capability needs must be established. These should be based on requirements for storage, transportation, and disposal, and include determination of appropriate timing and location.

Discussion. For this discussion, the term processing includes a wide range of fuel preparation or conditioning actions. These range from simple canning to chemical dissolution and separation.

Before any processing technologies are developed and employed, fundamental requirements must be established. These WAC should be based on factors such as fuel form for onsite storage, shipping, and repository. Timing is also important. Fuels should not be processed unnecessarily or before requirements are established. However, in some cases, there is an immediate need for processing to continue safe storage. As a general rule, the most cost-effective strategy is to first establish the requirements and objectives of processing, select a process or processes to meet those requirements, then process to the minimum extent necessary to meet requirements. Processing should be done on a time scale consistent with current safety and ultimate disposal needs, but should not be done sooner than needed. Other factors affecting processing decisions include: (a) sitespecific needs; (b) whether new development is required or if existing technologies and facilities can be employed; and (c) sharing capabilities between sites. DOE's Technology Development Plan must be integrated with technology and timing requirements (DOE, 1992a).

\section{Storage}

\section{Issue \#9}

DOE regulatory requirements for onsite wet and dry storage while awaiting shipment to the repository are needed.

Discussion. Current DOE order regulations for fuel storage are limited. These include orders such as DOE Order 6430.1A, Section 1320, Irradiated Fissile Material Storage Facilities, which provides design criteria for a new facility or facility addition for storing spent fuel. It is primarily for pools away from a reactor. Other DOE orders give guidance on general facility safety requirements (e.g., DOE Orders 5481.1B and 5480.5), but are not oriented to spent fuel storage. Guidance similar to NRC 10 CFR 72, Licensing Requirements for the Independent Storage of Spent Nuclear Fuel and High-Level Waste, is needed for all aspects of fuel storage, including dry storage facilities.

DOE Order 5820.2A, Radioactive Waste Management, establishes DOE policies, guidelines, and minimum requirements by which DOE manages its radioactive and mixed waste and contaminated facilities. The current order addresses high-level, transuranic, and low-level waste, waste containing naturally occurring and accelerator-produced radioactive material, and decommissioning of contaminated facilities. The Order defines radioactive waste as "solid, liquid, or gaseous material that contains radionuclides regulated under the Atomic Energy Act of 1954, as amended and of negligible economic value considering costs of recovery." With the curtailment of reprocessing, SNF now falls within the definition of waste in DOE Order 5820.2A. This order is being revised, and a spent fuel chapter will be included. 


\section{Issue \#10}

MRS and first repository priorities and fuel receipt schedules are needed to determine the time schedules for onsite storage.

Discussion. DOE fuels are currently stored in a variety of facilities. Some are quite modern and meet current requirements. Others are outdated, do not meet current requirements, and may pose a safety hazard. For each type of fuel and storage location, the anticipated length of storage time must be determined. This would be based on the time when the fuel in question will be shipped somewhere else for storage or disposal. The time required for storage must be compared with the anticipated life of the facility to establish if new interim storage is needed, and the timing for new interim storage, before the fuel is removed.

Another problem is that some DOE fuels will probably not be accepted for storage in MRS or the first repository. Thus, whether or not the fuels will be accepted, and the schedule dates for those that will be accepted, must be established for all fuels. For fuels unlikely to go in MRS or the repository, additional requirements for longer term storage must be established and solutions must be implemented.

The OCRWM publishes its annual capacity report (DOE, 1991b), which contains information on the annual capacity allocations for the projected ten-year period of initial Federal Waste Management System operations. This and other relevant information must be researched to determine DOE fuel acceptance.

\section{Issue \#11}

Requirements for onsite storage capacity must be determined and plans must be established for implementation. These must be based on location, the type and condition of fuels to be stored, and the potential length of storage time.

Discussion. Because of the way DOE's spent fuel management system has evolved, most fuel is stored in pools associated with reactors or reprocessing plants. Many of these pools do not meet current requirements, and must be modified or the fuel removed to another storage facility. These pools were generally not intended for long-term storage. Features such as water cleanup systems, cooling systems, and the need for constant control of water chemistry make their operations expensive. Also, for continued safe storage they must be designed to current seismic standards, have ventilation control, and leak detection.

Pool storage capacities can be increased by reracking to improve storage density. Reracking is a common and proven method of increasing pool capacity. Pool capacity may also be increased by consolidating fuel assemblies where practical. Consolidation also has the potential to increase repository capacity. Not all types of fuel, particularly fuel owned by DOE, is capable of consolidation. Several consolidation demonstration projects have been conducted, with limited success (Viebrock and Malin, 1982; Towne, 1982; Bassler, 1984; Sheldon, 1984; Judson et al., 1985; IAEA, 1991; and GAO, 1992). Although consolidation reduces fuel volume, waste consisting of non-fuelbearing components is generated, which must be stored or disposed. Also, increasing pool capacity does not solve the problems inherent in pool storage discussed above. 
An increasingly popular method for civilian reactors to store fuel is dry storage. Commercial interests, in cooperation with DOE, have developed and demonstrated several dry storage concepts. These include metal and concrete casks, concrete shielded horizontal dry storage canisters, and modular vaults (Johnson et al., 1983; McKay and Smith, 1984; Newman, 1985; DOE, 1984; Van Hoomissen and Judson, 1985; Schoonen et al., 1986; and GAO, 1992).

Since the date when DOE can ship fuel away from current sites is uncertain, and likely to be well into the 21st century, DOE must evaluate its current storage capacity and select storage options suitable for timing and fuel types required. Since dry storage technologies have been developed for commercial fuel with bundled fuel pins and low enrichment, their applicability for DOE's wide variety of fuel types must be established and perhaps demonstrated.

\section{Issue \#12}

A determination is needed on the optimum location or locations for storing spent fuel until the repository is available.

Discussion. DOE currently stores fuel at several different sites around the country. The largest inventories are located where production and reprocessing were previously performed: Idaho National Engineering Laboratory, Hanford Site, and Savannah River Site. Consideration has been given to transferring some or all SNF to a single site for long-term storage, or storing individual fuel types at specific facilities. This might yield benefits such as cost savings, improved security, and the ability to use a single fuel processing or conditioning facility. However, it would also involve a massive transportation effort, and would be a sensitive issue with the host site state government. Unless a deliberate effort is made to consolidate storage, it will continue at the current sites.

\section{Transportation}

\section{Issue \#13}

An assessment is needed of SNF transportation system requirements. This includes determining the transportation capacity and timing for moving spent fuel between storage and conditioning facilities, and from those facilities to the repository. It also includes institutional plans for dealing with affected state and local governments, and other interested parties.

Discussion. At the presert time, DOE's transportation needs for spent fuel are being met. It is unlikely that there will be a significant change in the near term, unless fuel is shipped to other sites for storage. However, as the repository begins accepting waste, transportation requirements will change significantly. SNF must be transported in casks certified to stringent requirements by the iNRC. Where large numbers of shipments are involved, considerable cost savings can result from optimizing the cask design to hold the maximum number of fuel assemblies. Evaluations should be performed that determine needs such as capacity, timing, routing, facility interface, etc. Transportation will also arouse considerable interest among state and local governments, the news media, opposition organizations, and others. An institutional plan for proactively addressing these concerns should be developed. 


\section{Issue \#14}

Cask requirements for the transportation system should be determined.

Discussion. DOE's present requirements for spent fuel transportation casks is being met by its current fleet, except for site-specific problems at ORNL and Brookhaven. It is unlikely that there will be a significant increase in need for shipping casks in the near term, unless fuel is shipped to other sites for storage. However, as the repository begins accepting waste, or if regional fuel storage is implemented, fleet requirements will increase. These requirements must be established in sufficient time to develop and acquire the required number and types of casks. Funding for cask development and procurement must be scheduled to meet transportation requirements.

DOE's OCRWM is developing casks for shipping commercial fuel. These casks are currently in final design and initial testing for certification. However, they are designed for the geometry, enrichment, burnup, and other parameters associated with commercial fuel. Their suitability to DOE fuel must be evaluated. It is likely that new or modified designs will be needed for DOE fuel.

\section{Disposal}

\section{Issue \#15}

Will the fuel in its disposed condition be critically safe for all possible scenarios, or does the configuration require maintenance of geometry or exclusion of water to maintain its subcritical condition?

Discussion. One factor in assessing the conditioning required for disposal is criticality safety. The fuel must remain safe for all possible configurations, including geometrical rearrangement due to geologic forces, and intrusion of water, which will moderate neutrons. The repository design is oriented toward commercial fuel, with pin-type geometry and low enrichment. Since DOE fuel has a much wider range of geometrical configurations and enrichments, criticality after disposal must be evaluated in determining the required processing. 


\section{SITE-SPECIFIC ISSUES}

\section{Hanford Site}

Three site-specific issues have been identified for the Hanford Site.

\section{Issue \#16}

Fuel storage facilities to be used for interim storage of spent fuel must be upgraded to meet DOE and regulatory compliance standards.

Discussion. In late 1990, DOE determined that the plutonium contained in irradiated fuel stored at Hanford was no longer needed for defense or research purposes. DOE further determined that alternatives for interim storage of irradiated fuel at Hanford should be considered and that a new environmental impact statement (EIS) be prepared to provide input on the environmental impacts of all viable alternatives. The EIS will evaluate Hanford Defense Reactor [N Reactor and Single Pass Reactor (SPR)] fuel, Fast Flux Test Facility (FFTF) fuel, Shippingport Naval Reactor PWR Core II fuel, and miscellaneous fuel. The "Notice of Intent to Prepare an Environmental Impact Statement on the Interim Storage of Hanford Irradiated Fuel, Richland, Washington" (DOE, 1992b) proposes three alternatives for the storage of spent fuel.

- Continue to store the fuel in existing storage facilities ("no action" alternative).

- Store the fuel in existing storage facilities after these facilities have been modified to comply with minimum requirements for interim storage of irradiated fuel.

- Provide a new alternative storage capability at the site, a system that would comply with current standards for interim storage of irradiated fuel. If this alternative is used, the Hanford Defense Reactor fuel may have to be converted to a more stable form for interim storage.

A decision on which of these alternatives is most appropriate for spent fuel management has not been made.

Use of current storage basins for spent fuel storage is problematic. Because the 105-KE and $105-\mathrm{KW}$ basins were constructed in the 1950 s, it is unlikely that they can comply with current DOE requirements for storage of irradiated fuel. Seismic studies and DOE order compliance evaluations are underway to determine if the two basins can meet current seismic requirements. A compliance evaluation will identify those areas where the $105-\mathrm{KE}$ and $105-\mathrm{KW}$ basins do not meet DOE Order 6430.1A construction standards. If the structures cannot withstand the site design basis seismic event, cost feasibility to bring $105-\mathrm{KE}$ and $105-\mathrm{KW}$ up to standards needs to be assessed.

Failed N Reactor fuel cladding has contaminated the water of the 105-KE basin with dissolved radionuclides. Continued interim storage of the $\mathrm{N}$ Reactor fuel is required until fuel disposition is complete. Once the irradiated fuel is removed, no further roles are proposed for the basins. Activities will focus on deactivation. 
Actions currently planned to reduce the risks associated with storing fuel in the basins include:

- 105-KE and 105-KW basins fuel encapsulation and repackaging. This activity involves taking appropriate action to ensure that all stored fuel in these basins is stored in capped, stainless steel canisters. An environmental assessment is being prepared for this proposed action, and a finding of no significant impact report is anticipated in the near future.

- 105-K basins cooling system activities. Air-cooled chillers for cooling the basin water will be installed to reduce the potential for a leak to the river via the current water-cooled heat exchangers. A related activity involves downsizing the water supply system to match the demand and replacing piping, pumps, and other aging equipment to improve the reliability of the overall system.

Similarly, storage capacity at the three FFTF storage locations may not be sufficient to support FFTF activities prior to the implementation of the EIS Interim Storage of Hanford Irradiated Fuel record of decision. The EIS addresses environmentally safe interim storage of irradiated fuel containing significant quantities of plutonium and highly radioactive fission products. If necessary, an option is to expand storage capacity by employing interim aboveground dry storage in casks. These casks would store irradiated fuel with a decay heat of less than 250 watts. Any sodium contamination would be removed from the irradiated fuel prior to emplacement in dry storage. The storage casks must comply with appropriate DOE requirements and be stored outside on a concrete pad in the 400 Area. This option, however, would require an environmental assessment/EIS for implementation.

The T Plant that houses PWR Core II fuel needs to be maintained in some form until a planned fuel disposition program can be implemented. Fuel assembly disposition will be defined as part of the irradiated fuel EIS. Because of the age of the facility, alternatives for repair services will be considered. It is expected that facility deactivation will occur once the fuel is dispositioned.

Irradiated fuel (in sealed containers) stored in the 200 Area Low-Level Burial Ground is no longer soil-covered in order to improve retrieval. Continued interim fuel storage of irradiated fuel in the $\mathbf{3 0 0}$ Area is required until fuel disposition is complete. Facility deactivation for transfer to surplus facilities management is planned under mission/program activities.

\section{Issue \#17}

With spent fuel destined for disposal, it must be determined how to prepare the fuel for disposal.

Discussion. Several options are under investigation that would prepare Hanford's spent fuel for shipment to the geologic repository. The Hanford nuclear facilities mission area has the responsibility to store, manage, and disposition the inventories of nuclear materials associated with the nuclear facilities. The alternatives for the irradiated fuel disposition strategy include the following: 
- $\quad$ N Reactor and SPR fuel, which is metallic fuel, can be oxidized (reduces pyrophoricity of the fuel) and then packaged for repository disposal. PWR Core II and FFTF oxide fuels would be packaged directly for disposal (assuming these fuels meet the WAC for the storage and/or disposal facilities).

- Directly package N Reactor and SPR fuel for disposal. This would require qualification of a new repository waste form.

- Vitrify the N Reactor and SPR reactor fuels into a glass-like matrix for repository disposal.

- Reprocess all fuels by separating the uranium and plutonium, and dispose of the reprocessing waste along with similar materials existing at the site. The recovered uranium and plutonium would be added to the existing inventories of these materials for disposition.

- Transport the fuels to another site for processing. N Reactor and SPR fuel may require pretreatment to allow shipment.

No decision on a preferred approach can be finalized until WAC are established for interim storage and the geologic repository.

\section{Issue \#18}

SNF stored at Pacific Northwest Laboratory's (PNL's) 324 Building must be transferred to another storage facility.

Discussion. The majority of spent fuels at PNL is stored dry in vertical storage racks in a hot cell in the 324 Building. This facility is adequate for storage of PNL's spent fuels, and there are no problems associated with the storage of these fuels. However, PNL does plan to decontaminate and decommission this hot cell by 1994 and transfer the fuel bundles to another storage facility, likely at another facility within the Hanford Site. ${ }^{b}$ Such transfers will require approved shipping casks.

\section{Idaho National Engineering Laboratory}

Spent fuel management issues at the INEL revolve around the storage and disposition of the large inventory of spent fuels and related waste stored at the site. Fuel is stored at Power Burst Facility (PBF), Test Reactor Area (TRA), Test Area North (TAN), Idaho Chemical Processing Plant (ICPP), Argonne National Laboratory-West (ANL-W), and Naval Reactors Facility (NRF) in both wet and dry storage facilities. Spent fuel planned for storage at the INEL continues to be generated at ATR, ANL-W, and by the Navy. Navy and ATR fuel is sent to the ICPP for storage after an initial cooling period. ANL-W is developing a system to reprocess its spent fuel into new fuel for EBR-II as part of the research mission. NRF spent fuel plans will not be addressed in this document. Navy fuel is "classified" and specific information is not included. Approximately 874 metric tons of spent fuel is stored at the INEL.

b. Katayama, B., 1992, Battelle Pacific Northwest Laboratory, personal communication. 
The inventory of spent fuel at the INEL can be categorized by cladding type, and includes zirconium-clad commercial and research reactor fuel, including Three Mile Island core debris; stainless-steel-clad Fermi Blanket and other research fuel; graphite matrix Fort Saint Vrain and Peachbottom fuel; and aluminum-clad Advanced Test Reactor and other research reactor fuels.

The following are specific issues requiring resolution (DOE, 1992c):

\section{Issue \#19}

There is no clear ownership of some spent fuel at the INEL.

Discussion. Although EM is eventually expected to take ownership of these fuels, multiple responsible agencies currently own fuel stored at the INEL. In many cases, ownership has not been clearly established. Among the owners are EM, OCRWM, DOE Defense Programs, and NRC. This diverse ownership will adversely impact the storage and transportation of spent fuel until EM takes title.

\section{Issue \#20}

Spent fuel storage facilities at the INEL are inadequate for long-term custodial care, and second generation storage facilities or modifications may be required.

Discussion. Spent fuel storage facilities are inadequate for current and projected needs. With the exception of CPP-666, the spent fuel storage pools at TAN, PBF, and CPP-603 are out of compliance with regulatory requirements. Facilities are needed to store TMI-2 core debris, PBF fuel, TRA fuel, and Virginia Electric Power Company (VEPCO) fuel until disposal is available. The construction of storage facilities that meet regulatory compliance is needed. One major problem affecting the overall picture of spent fuel storage at the INEL is the indefinite opening date of the geologic repository for high-level radioactive waste, which makes the required storage period uncertain. The lack of waste acceptance criteria (WAC) for the repository also makes preparations for long-term interim storage uncertain (DOE, 1992c).

Spent fuel storage options include (a) a spent fuel dry aboveground storage facility, (b) spent fuel dry belowground storage facilities, and (c) additional wet storage capacity. The INEL is proceeding to establish dry storage for spent fuel at TAN. The storage term has not been established, and the final disposition of spent fuel has not been determined.

ICPP is in the process of reracking the CPP-666 fuel storage basins, and much of the fuel presently stored at CPP-603 will be moved to CPP-666. The remaining fuel will be moved to the CPP-603 south basin, which is much safer for fuel storage. The goal is to have all of the fuel moved by 1997 . All of the fuel will be recanned and moved when the proposed canning facility is completed. No additional wet storage facilities are planned.

The INEL is proceeding to establish dry storage for spent fuel at TAN. The storage term has not been established, and the final disposition of spent fuel has not be determined. 
Similarly, ICPP is planning for a dry canning facility with additional dry storage capabilities from the deteriorating spent fuels stored in the aging wet storage facilities. Belowground dry storage silos are available at ICPP and additional silos have been proposed. A Short Form Data Sheet and a Justification of Mission Need document have been submitted and Energy Systems Acquisition Advisory Board meetings are planned for the project

Issue \#21

Current TAN Hot Cell and Hot Shop facilities are not adequate for long-term inspection and maintenance of spent fuel storage casks.

Discussion. Spent fuel is currently stored in four dry storage casks at TAN. To ensure that safe storage will continue, the TAN Hot Shop must remain available in standby to perform maintenance or respond to emergencies. However, continued operation is contingent on continued funding to perform other activities. A secure funding base for the Hot Shop is needed, or the casks must be moved to another location. The need for a canning and characterization facility exists that may recuire modification to current Hot Cell facilities for an interim measure. The proposed construction of a canning facility at ICPP will meet the long-term needs.

\section{Issue \#22}

Characterization of various types of spent fuel has not been accomplished.

Discussion. A spent fuel characterization facility is needed at the INEL to make several key decisions concerning disposition. Spent fuel must be characterized to establish or meet requirements for treatment, storage, packaging, transportation, and final disposition. Characterization will help determine the processing options. Some fuels will require direct disposal, whereas others will require predisposal processing. Spent fuel from external sources could have a history or configuration that requires special characterization. PBF and TMI fuels have unique characteristics that may make the fuels RCRA-regulated. Presently, the required methods and procedures do not exist. A spent fuel characterization facility will be necessary to accomplish all of these requirements.

The dry canning facility planned for ICPP will include areas and equipment for performing the characterization activities. The methodology will be developed in existing facilities; actual work on the various spent fuels will be performed in the canning facility.

\section{Issue \#23}

Processing options for INEL spent fuel are not defined. A spent fuel handling and treatment facility may be needed at the INEL.

Discussion. Much of the INEL spent fuel is in a form that appears to be unacceptable to the projected or proposed requirements for interim storage or the repository; a prominent example is the TMI-2 core debris. Acceptable waste forms are required for transportation, storage, and disposal. For example, disposal or transfer of INEL TMI spent fuel materials could require removal or elimination of significant void, nonfuel diluent materials, and moisture. An approach for inspection and treatment is described in DOE's Technology Development Plan (DOE, 1992a). 
Westinghouse Idaho Nuclear Company, Inc. (WINCO) has a draft development plan for the conversion of spent fuel into acceptable waste forms. The plan involves the characterization of the fuel and the development of technologies that will condition the fuel so that it will meet the storage or repository requirements. The plan includes laboratory and pilot plant work. A wide variety of present technologies is being evaluated, and new technologies are being developed.

\section{Issue \#24}

Transportation and handling of spent fuel is not clearly defined, particularly for fuel stored at TAN which must use a public highway for movement to ICPP.

Discussion. Licensed transportation systems are needed at the INEL to transport spent fuel. Spent fuel materials will be transported from PBF and TRA to a storage location at ICPP in compliance with regulations governing onsite transportation and storage of those materials. Transportation to and from TAN is on a public highway, which requires NRC-certified casks or a Department of Transportation (DOT) exemption. A program is in place to upgrade transportation capabilities to meet compliance requirements (DOE, 1992c).

\section{Savannah River Site}

The primary spent fuel management issue at the SRS relates to recent decisions to terminate reprocessing.

\section{Issue \#25}

If the SRS reprocessing facilities are indeed shut down, a major issue that is likely to arise is related to providing interim storage for SRS fuels.

Discussion. Since original storage capacities built at the site did not include the possibility of a complete shutdown of reprocessing operations, current onsite storage capabilities are limited. Also, the opening of a permanent geologic repository is not likely to be completed in the near future. Therefore, one of the issues that needs resolution is how to manage fuels that would not be reprocessed anymore. As with the case of other sites, one option is to investigate methods of dry storage.

Even if reprocessing is not stopped, there are a number of nonprocessable fuels currently in storage at the Receiving Basin for Offsite Fuels (RBOF). The fuels that are currently considered nonprocessable are divided into four categories:

- Category $\mathrm{A}-$ Zirconium-clad uranium metal, uranium alloy, and $\mathrm{UO}_{2}$ fuels

- Category B - Mixed uranium-plutonium oxide fuels

- Category C - Mixed uranium-thorium oxide fuels

- Category D - Fuels containing zirconium in both the core and the cladding. 
Even if reprocessing is continued at SRS during the five- to six-year stabilization cleanout period, only aluminum-clad fuels will be reprocessed. Nonreprocessable fuels will be treated to permit disposal without reprocessing, and all non-aluminum fuels are considered nonreprocessable.

\section{West Valley Demonstration Project}

Spent fuel at the West Valley facility was intended for shipment to the INEL as part of a cask demonstration project. However, in 1991, the Secretary of Energy notified the Idaho Congressional delegation that the fuel would not be shipped to Idaho, but would be stored at West Valley until shipments can begin to a Federal MRS facility or geologic repository (Watkins, 1991).

\section{Issue \#26}

West Valley pool storage is not in compliance with current DOE orders for fuel storage. Options for continued interim storage or shipment to another facility are being evaluated.

Discussion. DOE Order 6430.1A specifies requirements for new DOE pool storage. Some key elements of this Order are not met at West Valley. A recent evaluation of the facility concluded that the facility does not meet requirements for leak detection and leak control. Also, damaged fuel assemblies must be placed in canisters. West Valley has begun identifying and evaluating options for complying with the DOE Order. New facilities or enhancements to the existing facility may be required. If fuel remains in storage at West Valley, further environmental review will be required for long-term storage.

Fuel at West Valley is owned by OCRWM, and the facility is managed by EM. OCRWM funds fuel inanagement activities, such as storage evaluations, safety analysis, and fuel pool operation and maintenance.

DOE's contract with New York State requires that if the fuel is not removed before December 31,1994 , fuel storage penalty payments of $\$ 104,746$ per quarter must be made to New York State beginning in April 1995 (Agreement between New York Energy Research and Development Authority and DOE, November 1986).

\section{Oak Ridge National Laboratory}

The High Flux Isotope Reactor (HFIR), currently operated at ORNL, discharges 12 cores of spent fuel per year. In the past, spent fuel was stored for one to two years in the spent fuel pool at ORNL, and then shipped to the SRS for reprocessing. U-235 was recovered from the spent fuel and returned to the Y-12 plant at ORNL, mixed with U-235 from reprocessed SRS fuel, and used to manufacture new fuel for the reactors at SRS. ${ }^{c}$

Small amounts of spent fuel and miscellaneous fuel-related materials from commercial reactors were received at ORNL for research projects. These materials are dry stored in specially designed

c. Flanagan, G., 1992, Oak Ridge National Laboratory, "An Overview of the Spent Fuel Storage Facilities for the High Flux Isotope Reactor," personal letter from G. F. Flanagan to Mark Abashian. 
facilities at the 3019 and 4501 Buildings. These facilities provide adequate temporary storage of these materials until a final geologic repository is opened. There are no problems or issues related to the storage of these materials. ${ }^{d, e} f$

Spent fuel management issues at ORNL relate to the fact that fuels are no longer reprocessed at Savannah River. Although SRS has identified 20 locations in its storage array that are available for storage of HFIR spent fuel, ORNL's lack of a certified spent fuel shipping cask prevents the transportation of these fuels from ORNL to SRS. This requires that the spent fuel be stored on site in the spent fuel pool at ORNL. As at other locations, the management issues relate mostly to shipping and storage. Specific problems are as follows:

\section{Issue \#27}

Certification for a shipping cask for the HFIR spent fuels has not yet been obtained.

Discussion. After several years of effort, attempts to certify a cask were terminated. A contract has been issued to General Electric to provide an NRC-certified cask to DOE.

\section{Issue \#28}

Storage capacity in the pool at ORNL has been expanded, but will be filled by February 1994 at the current rate of spent core discharge from the HFIR.

Discussion. If fuel cannot be shipped off site, or storage capacity cannot be expanded, the reactor most likely will have to be shut down. In addition the purchasing a new cask, ORNL is developing a conceptual design for racks to enhance HFIR spent fuel pool storage capacity, and soliciting studies to determine the feasibility of storing HFIR spent fuel elements on site in dry storage.

\section{Issue \#29}

As of April 1992, ORNL has stored 73 spent fuel elements from the Bulk Shielding Reactor (BSR). This reactor is shut down, but before it can be permanently decommissioned, the fuel must be removed.

Discussion. This fuel was also slated to be sent to SRS, but will not be shipped until a shipping cask is approved.

d. Krichinsky, A. M., 1992, Oak Ridge National Laboratory, personal communication.

e. Osborne, M., 1992, Oak Ridge National Laboratory, personal communication.

f. Pearson, R., 1992, Oak Ridge National Laboratory, personal communication. 
Spent fuel elements from both the BSR and HFIR have been stored in the pool since 1985, and are showing signs of corrosion.

Discussion. Corrosion of the fuel makes handling fuel elements difficult and exacerbates the problems of long-term underwater storage. ${ }^{\text {B }}$ Dry storage options are being evaluated.

Issue \#31

Plans for the Advanced Neutron Source Reactor are predicated on its spent fuel being shipped to the SRS for reprocessing.

Discussion. ORNL is designing a new reactor, the Advanced Neutron Source Reactor, which will replace the HFIR and the High Flux Beam Reactor (HFBR) at Brookhaven. Development of this new reactor will depend on either new storage capacity at ORNL, or certification of a shipping cask and agreements with the State of South Carolina that will aliow shipment of spent fuel to Savannah River.?

\section{Brookhaven National Laboratory}

Spent fuel from the High Flux Beam Reactor (HFBR) is currently stored in a water-filled canal system that allows for radioactive decay of fission products and removes heat generated from the spent fuel. Problems that have been identified with the management of spent fuel from HFBR relate to transportation and storage capacity, and are as follows:

\section{Issue \#32}

Brookhaven does not have a DOE/NRC-approved cask for shipping spent fuel to other sites, thereby requiring that all HFBR spent fuel be stored on site in the interim storage canal system.

Discussion. To address this issue, the Brookhaven Reactor Division (BRD) plans to pursue acquisition of an approved shipping cask and develop a plan for spent fuel shipment by the end of FY 1993.

\section{Issue \#33}

The ability to transport spent fuel through New York City is uncertain because of continuing litigation to suspend shipment of spent fuel.

Discussion. To adiress this issue, the BRD plans to coordinate shipping plans with DOE-Chicago and DOE-Headquarters (Nuclear Energy and Environment Restoration/Waste Management).

g. Flanagan, G., 1992, Oak Ridge National Laboratory, "An Overview of the Spent Fuel Storage Facilities for the High Flux Isotope Reactor," personal letter from G. F. Flanagan to Mark Abashian. 


\section{Issue \#34}

As of April 1992, the current storage capacity of the canal system will be filled in 3.3 years, assuming the reactor continues to operate at its present level of 30 megawatts. If plans are carried out to increase reactor power to 60 megawatts in FY 1994, the canal storage capacity will be filled in 2.6 years.

Discussion. To address this issue, BRD plans to prepare existing stand-by storage racks for installation and consider building additional storage racks. Expanding the canal's storage capacity would extend the time until storage capacity is exceeded to 5.6 years, assuming the reactor continues to operate at 30 megawatts, and 3.7 years if power is increased to 60 megawatts.

\section{Sandia National Laboratories}

Because the research reactors (Annular Core Research Reactor, Sandia Pulse Reactors II and III, and Critical Assembly Reactor) operated at Sandia National Laboratories do not discharge spent fuel, SNL is faced with spent fuel management issues only when a reactor is decommissioned, and there are no plans to decommission any of the currently operating reactors. Available storage capacity is adequate for storage of the small inventory of fuel parts from the Sandia Pulse Reactor I, which was decommissioned in $1967 .^{\text {h }}$

\section{Los Alamos National Laboratory}

The major spent fuel management issue at LANL is related to onsite, interim storage of spent fuel.

\section{Issue \#35}

LANL is prohibited from shipping spent fuel to the INEL because of the State of Idaho moratorium on receiving radioactive waste and spent fuel from other states.

Discussion. The research reactor at LANL discharges about eight spent fuel elements per year. Although LANL has a relatively small spent fuel inventory, interim storage does present a severe problem for the reactor division because LANL had not anticipated having to provide longterm storage of the spent fuel and does not have adequate facilities or capacity for spent fuel storage. LANL has plans to increase the use of the research reactor, which would use about five times the amount of fuel currently used and generate approximately 40 spent fuel elements per year. This plan, however, is predicated on LANL resuming spent fuel shipments to another DOE facility. LANL obtained DOT-certified BMI-1 shipping casks to ship spent fuel. Because there is currently a moratorium on receipt of spent fuel ai the INEL, pending a record of decision or the INEL waste management EIS, LANL is investigating the possibility of shipping its spent fuel to the SRS. If

h. Schmidt, T. L., 1992, Sandia National Laboratories, personal communication. 
offsite shipping of spent fuel cannot be resumed, LANL may be forced to limit the use of the research reactor.

\section{Nevada Test Site}

Because no spent fuel remains at the E-MAD Facility and assuming no new shipments of spent fuel are received at the Nevada Test Site, there are no spent fuel management issues at this site.

i. Ramsey, G., 1992, Los Alamos National Laboratory, personal communication. 


\section{REFERENCES}

Agreement Between New York Energy Research and Development Authority and U.S.

Department of Energy on U.S. Department of Energy Spent Nuclear Fuel Located at the Western New York Nuclear Service Center, November 1986.

Bassler, E. A., 1984, "Westinghouse Fuel Consolidation Experience," presented to the Institute of Nuclear Materials Management.

Bechtel, D. A., 1986, "The Proposed Yucca Mountain Nuclear Waste Repository Program:

A Perspective from Local Government," Nuclear Materials Management XV, Institute of Nuclear Materials Management, New Orleans, Louisiana, pp. 614-616.

DOE, 1984, Transportation Business Plan: Strategy Options Document, DOE/RW-0007, U.S. Department of Energy, Washington, D.C.

DOE, 1991a, Integrated Data Base for 1991: U.S. Spent Fuel and Radioactive Waste Inventories, Projections, and Characteristics, DOE/RW-0006, Rev. 7, U.S. Department of Energy, Washington, D.C.

DOE, 1991b, Office of Civilian Radioactive Waste Management, Annual Capacity Report, DOE/RW-0331P, U.S. Department cf Energy, December.

DOE, 1992a, Idaho Chemical Processing Plant Spent Fuel and Waste Management Technology Development Plan, Draft, U.S. Department of Energy, April 24.

DOE, 1992b, "Notice of Intent to Prepare an Environmental Impact Statement on the Interim Storage of Hanford Irradiated Fuel, Richland, Washington."

DOE, 1992c, Idaho National Engineering Laboratory Waste Management Operations Roadmap Document," DOE/ID-10347, U.S. Department of Energy, Washington, D.C.

DOE News Release, 1992, "DOE Announces End to Reprocessing for Highly Enriched Uranium," R-92-115, U.S. Department of Energy, April 29.

DOE Office of Civilian Radioactive Waste Management, Quality Assurance Manual, DOE/RW-0214, current issue.

EPA, 1990, Evaluation of Spent Nuclear Fuel as Mixed Waste, U.S. Environmental Protection Agency, Washington, D.C.

GAO, 1992, Nuclear Waste: Development of Casks for Transporting Spent Fuel Needs Modification, GAO/RCED-92-56, U.S. General Accounting Office, Gaithersburg, Maryland. 
IAEA, 1991, Guidebook on Spent Fuel Storage, Technical Report Series No. 240, 2nd Edition, International Atomic Energy Agency, Vienna, Austria.

Johnson, A. B., Jr., E. R. Gilbert, and R. J. Guenther, 1983, Behavior of Spent Nuclear Fuel and Storage System Components in Dry Interim Storage, PNL-4189, Rev. 1, Pacific Northwest Laboratory.

Judson, B. F., J. E. Van Hoomisen, R. E. Hoskins, and J. B. Moegling, 1985, "Spent Fuel Management Options at the Utility Site," Nuclear Materials Management XV, Institute of Nuclear Materials Management, New Orleans, Louisiana, pp. 647-652.

McKay, H. S., and M. L. Smith, 1984, "The Vepco/DOE/EPRI Dry Cask Storage Cooperative Demonstration Program," Transactions of the American Nuclear Society, 46, p. 101.

McLeod, N. Barrie, 1992, "Progress in Spent Fuel Storage and Disposal," Journal of Nuclear Materials Management, May.

Newman, D. F., 1985, "DOE's Spent Fuel Storage Technology Research and Development Program," PNL-SA-12834, presented to the Institute of Nuclear Materials Management.

Pellettieri, M. W., and B. W. Welles, 1985, "State Issues and Recent Experience in Spent Fuel Shipping," Nuclear Materials Management XIV, Institute of Nuclear Materials Management, New Orleans, Louisiana, pp. 351-356.

Sheldon, T., 1984, "TVA Experimental Program on Consolidation," presented to the Institute of Nuclear Materials Management.

Schoonen, D. H., M. W. Fisher, M. F. Jensen, and C. K. Mullen, 1986, "Spent Fuel Storage Technology Demonstrations at the Idaho National Engineering Laboratory," Proceedings of Waste Management '86, Tucson, Arizona, pp. 121-126.

Smith, T. A., 1988, "Community Relations for the Transport of TMI-2 Core Debris," EGG-M-88192, November.

Towne, G. A, 1982, "Dry Spent Fuel Consolidation at the Barnwell Nuclear Fuel Plant," presented to the American Nuclear Society.

Tuck, J. C., 1990, "Materials Not Classified as Waste," DOE/EM-331, memorandum.

Van Hoomissen, J. E., and B. F. Judson, 1985, "What Should I Do With My Spent Fuel?" Proceedings of Waste Management '85, Tucson, Arizona.

Viebrock, J. M., and D. H. Malin, 1982, "Underwater Nuclear Fuel Disassembly and Rod Storage," presented to the American Nuclear Society.

Watkins, J., U.S. Secretary of Energy, letter to Senator S. Symms, U.S. Senate, and Congressman L. Craig, U.S. House of Representatives, October 23, 1991. 
